\title{
Greenhouse gas emission, water quality and straw decomposition as a function of rice postharvest field management
}

\author{
Camille Flores Soares ${ }^{1, \star} \mathbb{D}$, Enio Marchesan ${ }^{1}$ (D) Matias Henrique Prochnow $^{1}$ (D), Alisson Guilherme \\ Fleck $^{1}$ (D), Daivyd Silva de Oliveira ${ }^{1}$ (D), Uashington da Silva Riste ${ }^{1}$ (D), Jean Paolo Gomes Minella² (D), \\ Alessandro Dal'Col Lúcio ${ }^{1}$ (D) \\ 1. Universidade Federal de Santa Maria - Departamento de Fitotecnia - Santa Maria (RS), Brazil. \\ 2. Universidade Federal de Santa Maria - Departamento de Solos - Santa Maria (RS), Brazil.
}

\begin{abstract}
The objective of this paper was to evaluate the quality of water drained after the use of the knife-roller (an implement used to incorporate rice residues after harvest), the partial global warming potential ( $\mathrm{GGWP}$ ) and straw decomposition as a result of postharvest field management of irrigated rice. The experiments were conducted during the 2018 and 2019 offseason and the treatments consisted of several water drainage periods ( $0,3,6,9$ and 12 days) after a field pass with a knife-roller. In addition, a nonflooded harvest treatment without straw management was included. Analysis of drainage water three days after a pass with the kniferoller showed a reduction in total soluble solids by $94 \%$ compared to zero days. Nitrogen and soluble phosphorus were not influenced by the treatments. However, potassium levels increased as the drainage period increased, which is related to the period between harvest and drainage. As the electrical conductivity is influenced by the concentration of ions, it showed the same response curve as the potassium levels and, for $\mathrm{pH}$, there were small oscillations influenced by the temperature. The total $\mathrm{CH}_{4}$ emission and the pGWP were higher when the water depth remained for a longer period. However, the $\mathrm{N}_{2} \mathrm{O}$ emissions were higher in the absence of soil submersion. Water should be drained three days after a pass with the knife-roller in order to reduce potassium loss and suspended solids as well as pGWP. The use of the knife-roller accelerated the process of straw decomposition in relation to the unmanaged straw treatment.
\end{abstract}

Key words: global warming, knife-roller, methane, nitrous oxide, Oryza sativa.
Received:

Dec. 26, 2019

Accepted:

Jun. 22, 2020

Section Editor:

Hector Valenzuela

*Corresponding author:

camille-flores@hotmail.com

\section{INTRODUCTION}

After the harvest of irrigated rice, it is important to conduct the proper management of these areas in order to reduce the remaining dry mass and not to affect negatively the timely sowing period of the next crop. Among the practices that can be adopted, the use of cattle grazing in the area, the desiccation of the stubble or the incorporation of straw with the use of the knife-roller could be mentioned (Sosbai 2018). The knife-roller is one of the most frequently used management tools after the harvest of rice under saturated soil conditions. In addition, it is widely adopted by farmers in Argentina, Uruguay and Southern Brazil. This equipment consists of a roller with parallel blades, in which its load is determined through water or sand inside the roller (Silva et al. 2012). This process promotes the lodging of rice stubble by increasing the stubble's contact with the soil and by accelerating the straw decomposition. Furthermore, this equipment contributes to correct the 
tire tracks created by the harvest, factors that facilitate land preparation and the sowing of the following crop at the proper timing (Massoni et al. $2013 \mathrm{a}$ ).

However, after this process, it is necessary to drain the standing water, which carries suspended particles leading to the loss of nutrients adsorbed to the particles or present in the solution (Kondoh et al. 2019). Xiao et al. (2015) observed that the loss of nutrients N, P and sediments was reduced under controlled drainage. The authors proposed to increase the flood holding period in order to precipitate colloidal particles in suspension, as an alternative to decrease the level of sediments and nutrients in solution.

However, this management practice may impact greenhouse gas emissions since submersion alters the soil redox conditions, affecting microbial processes, which are the main responsible agents for the production of methane $\left(\mathrm{CH}_{4}\right)$ and nitrous oxide $\left(\mathrm{N}_{2} \mathrm{O}\right)$ in the soil (Jumadi et al. 2019).

In this context, it is important to adopt management practices which include the entire rice production system, not only the plant growing, because climatic conditions associated with the stubble management after harvest can also influence the $\mathrm{CH}_{4}$ and $\mathrm{N}_{2} \mathrm{O}$ emissions, during the period between rice crops.

Wu et al. (2018), evaluating greenhouse gas emissions as a function of rice postharvest, concluded that the maintenance of rice straw on the surface during the off-season enhances emissions of $\mathrm{N}_{2} \mathrm{O}$. On the other hand, the incorporation of straw on flooded soil contributes to higher $\mathrm{CH}_{4}$ emission (Sander et al. 2018). In this sense, it is necessary to adopt management practices that eliminate rice residues after harvest, aiming at their decomposition during the off-season to enhance sustainability by minimizing the emission of greenhouse gas.

Therefore, the objective of this study was to evaluate the water quality drained from rice fields after a pass of the kniferoller, its effect on the emission of $\mathrm{CH}_{4}$ and $\mathrm{N}_{2} \mathrm{O}$ and the partial global warming potential. In addition, this study aimed to determine the decomposition rate of plant residues as a function of the postharvest field management of rice.

\section{MATERIAL AND METHODS}

The experiments were conducted in the field during the 2018 and 2019 off-season in the municipality of Santa Maria ( $29^{\circ} 43^{\prime} \mathrm{S}, 53^{\circ} 43^{\prime} \mathrm{W}, 95 \mathrm{~m}$ altitude), RS, Brazil. The soil of the experimental area is classified as eutrophic arenic hexic planosol (Santos et al. 2018) and its climate is characterized, according to the classification of Köppen, as subtropical humid (Cfa), with an average annual precipitation of $1688 \mathrm{~mm}$ (Climate Data 2019).

The experimental design was a randomized block design with four replications and a $7 \times 15 \mathrm{~m}\left(105 \mathrm{~m}^{2}\right)$ experimental unit. The treatments consisted of several water drainage periods after a pass with a knife-roller $(0,3,6,9$ and 12 days) and a nonflooded harvest treatment without straw management. Soon after the rice harvest, the remaining straw was previously quantified, with $10758 \mathrm{~kg} \cdot \mathrm{ha}^{-1}$ in the first year and $10200 \mathrm{~kg} \cdot \mathrm{ha}^{-1}$ in the second year.

After rice harvest, straw samples of $0.15 \mathrm{~m}^{2}$ were collected in each experimental unit and then oven dried at $65{ }^{\circ} \mathrm{C}$ to a constant weight. The respective straw samples were placed in "mesh bags", with dimensions of $0.2 \times 0.15 \mathrm{~m}$ and mesh of $0.5 \mathrm{~mm}$, in order to determine the residue decomposition rates. These mesh bags were distributed in each experimental unit shortly after the pass with the knife-roller. Moreover, they were buried about $0.05 \mathrm{~m}$ in the straw incorporation treatments and they were left on the surface in the nonflooded harvest treatment. At 30, 60, 90 and 120 days after the pass with the knife-roller, one mesh bag was collected per experimental unit, then oven dried at $65^{\circ} \mathrm{C}$ to a constant weight, in order to verify the remaining straw biomass.

A knife-roller, manufactured by KLR implements (São Lourenço do Sul, RS, Brazil), ROC3000 model, 3 m wide and with estimated weight of $1500 \mathrm{~kg}$ was used. This operation was performed after the harvest rice, on April 7, 2018 (first offseason), and March 18, 2019 (second off-season), both with two passes in each plot and the presence of a $0.10 \mathrm{~m}$ water depth. During drainage, water samples were collected for quality analysis. For total suspended solids, $\mathrm{pH}$ and electrical conductivity $(\mathrm{EC})$, the samples were maintained at room temperature. For nutrient analysis, the samples were stored in a freezer at $-20^{\circ} \mathrm{C}$. 
The analysis of total suspended solids was conducted according to Shreve and Downs (2005) while the concentration of N, P and K according to Tedesco et al. (1995). The electrical conductivity was determined using a conductivity meter (Tecnal, 4MP model) adjusted to the temperature of the sample. The $\mathrm{pH}$ measurements were determined with a Tecnopon pHmeter, with a combined glass electrode and calibration of the device with a buffer solution pH: $4.0\left( \pm 0.05 / 25^{\circ} \mathrm{C}\right)$ and pH: $7.0\left( \pm 0.05 / 25^{\circ} \mathrm{C}\right)$.

The $\mathrm{CH}_{4}$ and $\mathrm{N}_{2} \mathrm{O}$ evaluations were performed on the day after each drainage event. After the last drainage event - 12 days after the pass with the knife-roller (DAKR), the evaluations were conducted weekly during three weeks (corresponding to 19, 26 and 33 DAKR) in order to determine the gas emissions after the application of all treatments. The evaluations were conducted with a system composed of a base and a camera, using a static closed chamber methodology (Mosier 1989). The dimensions of the galvanized steel square chambers were $0.2 \mathrm{~m}$ high and a base of $0.4 \times 0.4 \mathrm{~m}$.

During the gas analysis assessments, each chamber was fitted to the metallic base of the trough and then water was added in the trough to seal the chamber to prevent gas exchange with the outside. Before the evaluation, air circulation was performed during $30 \mathrm{~s}$ for homogenization of the internal atmosphere. The samples were collected with $20 \mathrm{~mL}$ polypropylene syringes at four-time intervals after placing the chamber on the base: $0,15,30$ and $45 \mathrm{~min}$. After each assessment, the samples were transferred to glass tubes (extainers) and analyzed through gas chromatography (Shimadzu GC - 2014 Greenhouse model).

Gas fluxes were calculated according to Eq. 1:

$$
\mathrm{f}=\Delta \mathrm{Q} / \Delta \mathrm{t} \times \mathrm{PV} / \mathrm{RT} \times \mathrm{M} / \mathrm{A}
$$

where: $\mathrm{f}$ is the flux of $\mathrm{N}_{2} \mathrm{O}$ or $\mathrm{CH}_{4}\left(\mathrm{~g} \cdot \mathrm{ha} \mathrm{a}^{-1}\right.$ per day); $\Delta \mathrm{Q} / \Delta \mathrm{t}$ is the alteration in gas concentration $\left(\mathrm{mol} \cdot \mathrm{h}^{-1}\right)$ in the chamber at the time of assessment; $\mathrm{P}$ is the atmospheric pressure (atm) inside the chamber, which was assumed to be $1 \mathrm{~atm} ; \mathrm{V}$ is the volume of the chamber $(\mathrm{L})$; $\mathrm{R}$ is the ideal gas constant $\left(0.08205 \mathrm{~atm} \mathrm{~L} \cdot \mathrm{mol}^{-1} \cdot \mathrm{K}^{-1}\right)$; $\mathrm{T}$ is the temperature inside the chamber at the moment of assessment $(\mathrm{K}) ; \mathrm{M}$ is the molar mass of the gas $\left(\mu \mathrm{g} \cdot \mathrm{mol}^{-1}\right)$; and $\mathrm{A}$ is the base area of the chamber $\left(\mathrm{m}^{2}\right)$. The accumulated emissions were calculated from the average $\mathrm{N}_{2} \mathrm{O}$ and $\mathrm{CH}_{4}$ fluxes between two consecutive assessments, multiplying the resulting value by the time interval, in days, between the two assessments. Based on the accumulated emission of $\mathrm{CH}_{4}$ and $\mathrm{N}_{2} \mathrm{O}$, and on the global warming potential of each gas in relation to $\mathrm{CO}_{2}-25$ times for $\mathrm{CH}_{4}$ and 298 times for $\mathrm{N}_{2} \mathrm{O}$, emissions were calculated as $\mathrm{CO}_{2}$ equivalents $\left(\mathrm{CO}_{2} \mathrm{eq}\right)$. The sum of these equivalents, named partial global warming potential $(\mathrm{pGWP})$, was calculated by: $\mathrm{pGWP}=\left(\mathrm{CH}_{4} \times 25\right)+\left(\mathrm{N}_{2} \mathrm{O} \times 298\right)$ in which $\mathrm{CH}_{4}$ and $\mathrm{N}_{2} \mathrm{O}$ are the emissions over the assessed period $\left(\mathrm{kg} \cdot \mathrm{ha}^{-1}\right)$.

The analyzed variables were submitted to test the assumptions of the mathematical model (normality of the errors and homogeneity of the variances). The variance analysis of experimental data was performed using the $\mathrm{F}$ test $(\mathrm{p}<0.05)$. The means of water-related variables, when significant, were submitted to polynomial regression analysis. For variables including nonflooded harvest treatments with drainage duration treatments, the Scott-Knott test $(\mathrm{p}<0.05)$ was used to perform the statistical analysis.

\section{RESULTS AND DISCUSSION}

The concentration of total suspended solids demonstrated a difference in both off-seasons, with higher concentrations observed in the drainage water performed immediately after the knife-roller pass (zero days). In the 2018 off-season, there was a reduction of $95 \%$ in relation to the other drainage events (Fig. 1a), while in the second off-season, there was a reduction of $93 \%$ (Fig. 1b). In the aforementioned experiments, the water depth was $0.10 \mathrm{~m}$, resulting in the drainage of $1000 \mathrm{~m}^{3} \cdot \mathrm{ha}^{-1}$ of water. In this volume of water, 2000 and $1300 \mathrm{~kg} \cdot \mathrm{ha}^{-1}$ of total solids were released in the drainage at zero days, in the first and second years, respectively. In comparison, a mean of $80 \mathrm{~kg} \cdot \mathrm{ha}^{-1}$ of total solids were lost via water drainage in the other treatment periods.

During the knife-roller pass, with the presence of standing water, a movement of soil particles occurs. The drainage performed right after this process does not allow the time required for the particles to precipitate, which increases the 
(a)

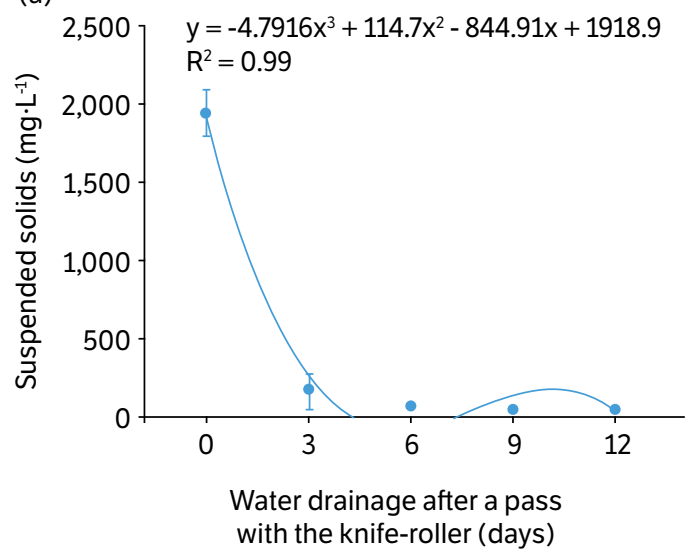

(c) 500$] \quad y=-2.0073 x^{2}+35.659 x+95.231$

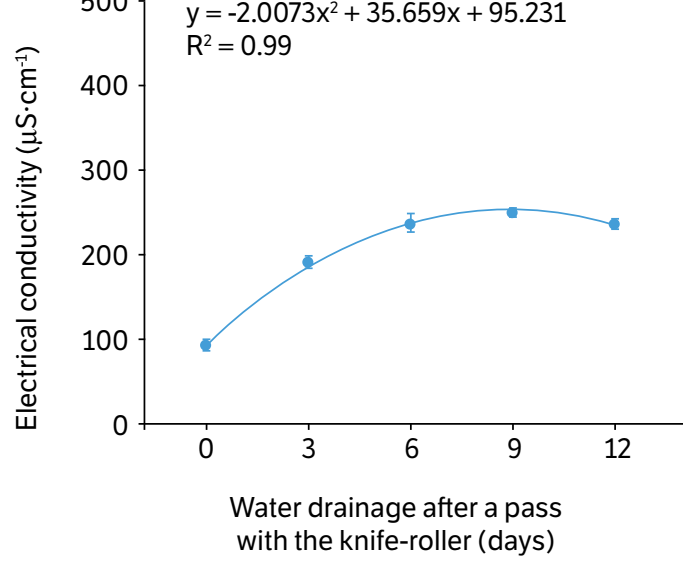

(e)

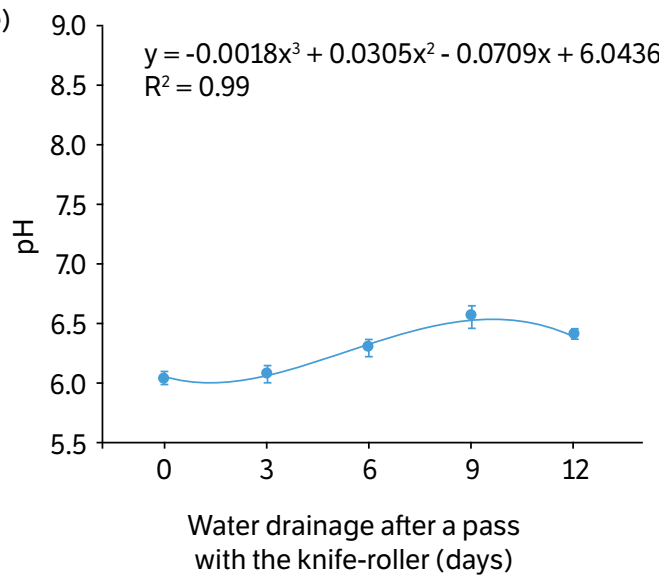

(b)

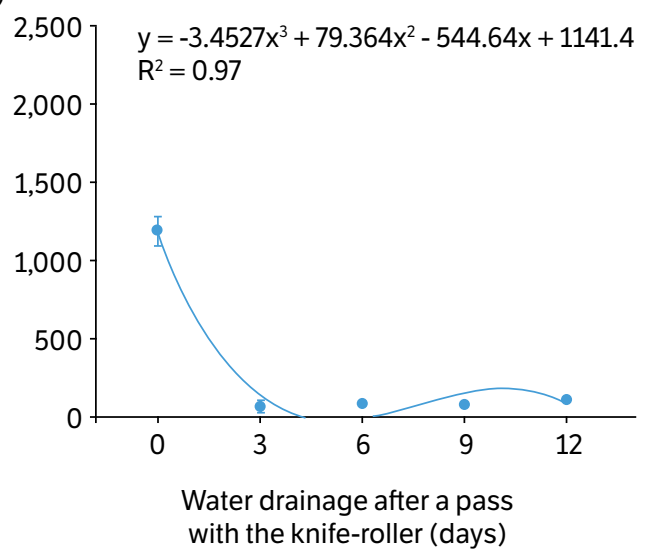

(d)

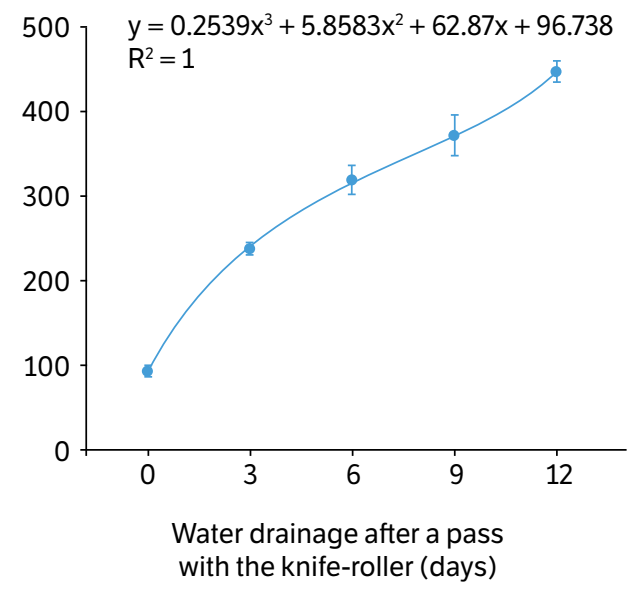

(f)

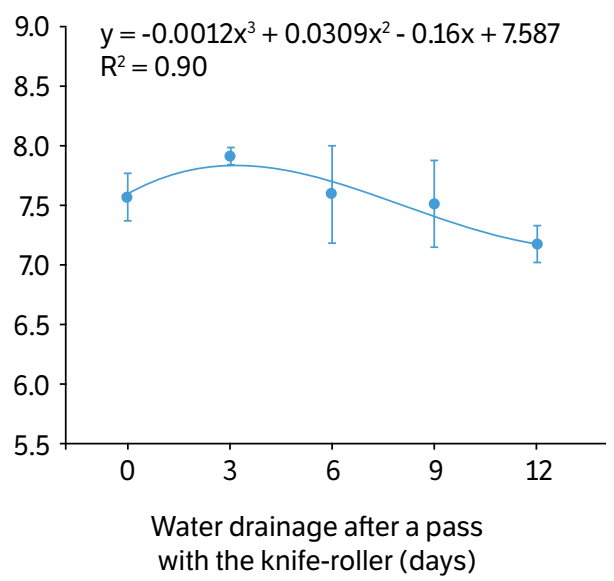

Figure 1. Total suspended solids $\left(\mathrm{mg} \cdot \mathrm{L}^{-1}\right)$, electrical conductivity $\left(\mu \mathrm{S} \cdot \mathrm{cm}^{-1}\right)$ and $\mathrm{pH}$ in drainage water as a function of irrigated rice postharvest field management during the 2018 ( $a, c$ and e) and 2019 (b, d and f) off-seasons.

suspended solids content. Kondoh et al. (2019) observed that, without a flood holding period before drainage, the precipitate contents increased from 54 to $2700 \mathrm{mg} \cdot \mathrm{L}^{-1}$, which corresponded to 54 and $2700 \mathrm{~kg} \cdot \mathrm{ha}^{-1}$ of solids lost by drainage water.

The EC of the water in both years showed a significant difference between the drainage periods. During the 2018 offseason, EC increased until the drainage period at 9 days with a small reduction at 12 days (Fig. $1 \mathrm{c}$ ). In the second off-season, EC increased until the last drainage period (Fig. 1d). Shah and Joshi (2017) define EC as the capacity of the medium to conduct electricity and that it is related to the amount of dissolved salts in the form of ions. Thus, EC followed the same trend as the potassium concentration, which was influenced by the salt content (Fig. 2a and b). 
(a)

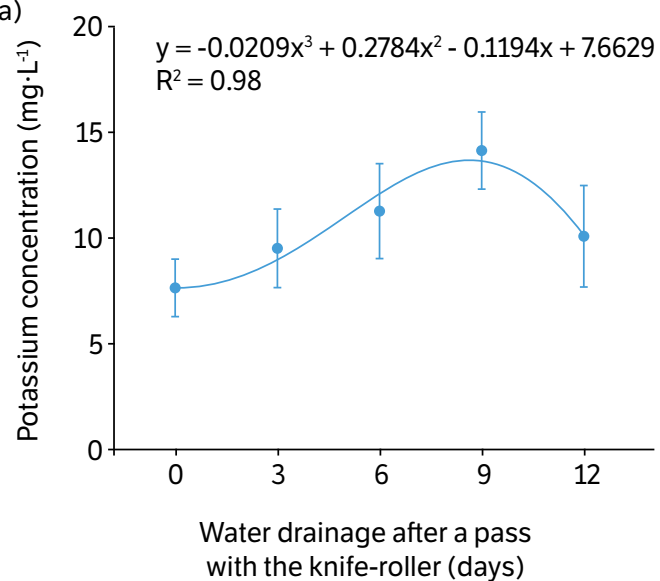

(c)

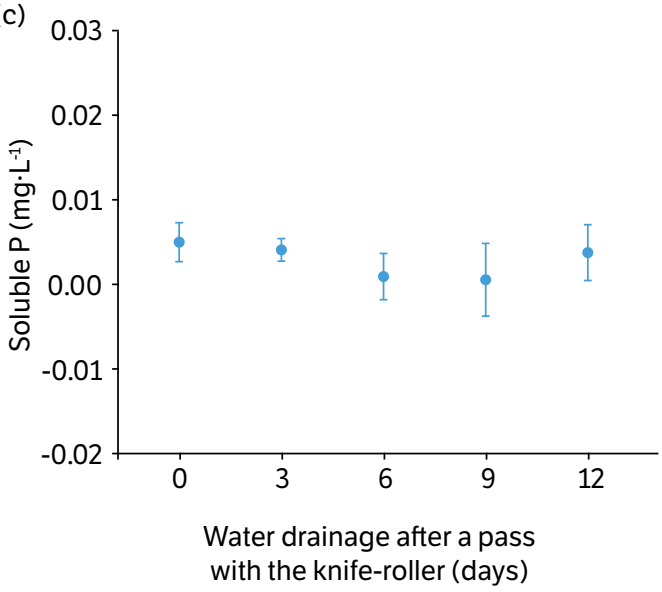

(b)

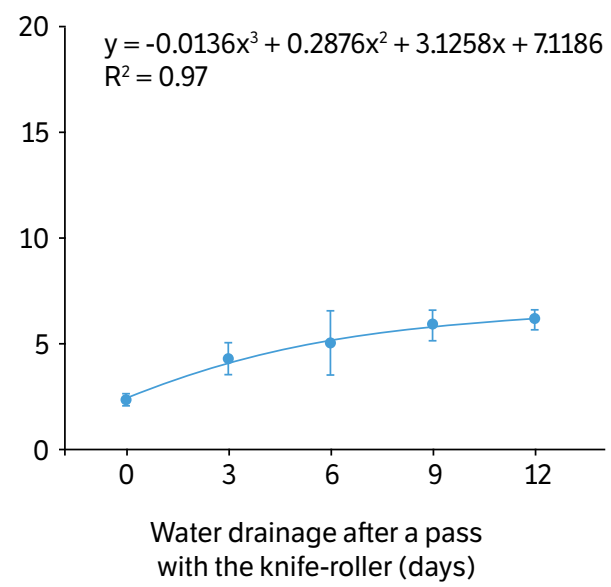

(d)

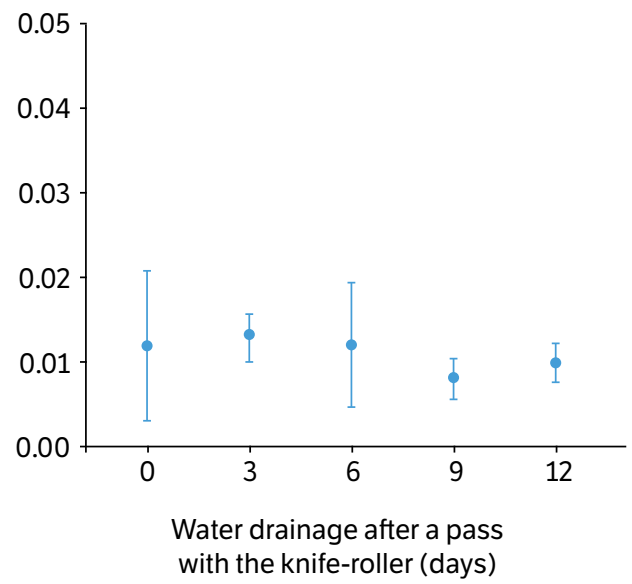

Figure 2. Potassium concentration $\left(\mathrm{mg} \cdot \mathrm{L}^{-1}\right)$ and soluble $\mathrm{P}\left(\mathrm{mg} \cdot \mathrm{L}^{-1}\right)$ in drainage water as a function of irrigated rice postharvest field management during the 2018 ( $a$ and $c$ ) and 2019 ( $b$ and d) off-seasons

For $\mathrm{pH}$, a significant difference was observed in both years, ranging from 6 to 7 (Fig. 1e) in 2018 and from 7 to 8 in 2019 (Fig. 1f). The observed oscillation is possibly due to the variation in organic matter dissolution and to temperature and solar radiation oscillations. A reduction in $\mathrm{pH}$ values was observed with increasing water temperature (Fia et al. 2015). In the 2018 off-season, the lowest $\mathrm{pH}$ values were around 6 at 24 and $25^{\circ} \mathrm{C}$. In the second off-season, the lowest value was 7.2 at $24{ }^{\circ} \mathrm{C}$ (Fig. 3a and b).

In the first year, there was a $47 \%$ increase in potassium content in water until drainage at 9 DAKR with a reduction at 12 DAKR (Fig. 2a). In 2019, there was a 60\% K increase by the last drainage period (Fig. 2b). Massoni et al. (2013 b), evaluating nutrient cycling as a function of rice postharvest, observed that the $\mathrm{K}$ release process from plant tissues was extremely fast with $90 \%$ of $\mathrm{K}$ contained in the residues released by 41 days after harvest. Therefore, it was possible to observe a reduction in the content of this salt. This reduction occurred possibly due to the interval between harvest and the assessment performed at $12 \mathrm{DAKR}$, which was 45 days. For the second off-season, the reduction of $\mathrm{K}$ was not observed since the interval between harvest and sampling was only 23 days. Thus, $\mathrm{K}$ had not yet likely been fully released from the residues.

Potassium is present in ionic form in plants, which allows it to be extracted from plant residues only with soil moisture, without requiring microbial interference activity ( $\mathrm{Li}$ et al. 2014). In addition, around 70\% of plant tissues contain watersoluble K, facilitating its leaching (Giacomini et al. 2003).

No significant differences were observed on both years with respect to soluble P levels, but extremely low values were registered (Fig. 2c and d), possibly related to its adsorption process by Fe and $\mathrm{Al}$ oxides and hydroxides. With the flooding of the soil, after consumption of molecular oxygen, anaerobic microorganisms use oxidized soil compounds as electron receptors. With these oxidation-reduction reactions, the $\mathrm{pH}$ values are changed, increasing the availability of elements like 


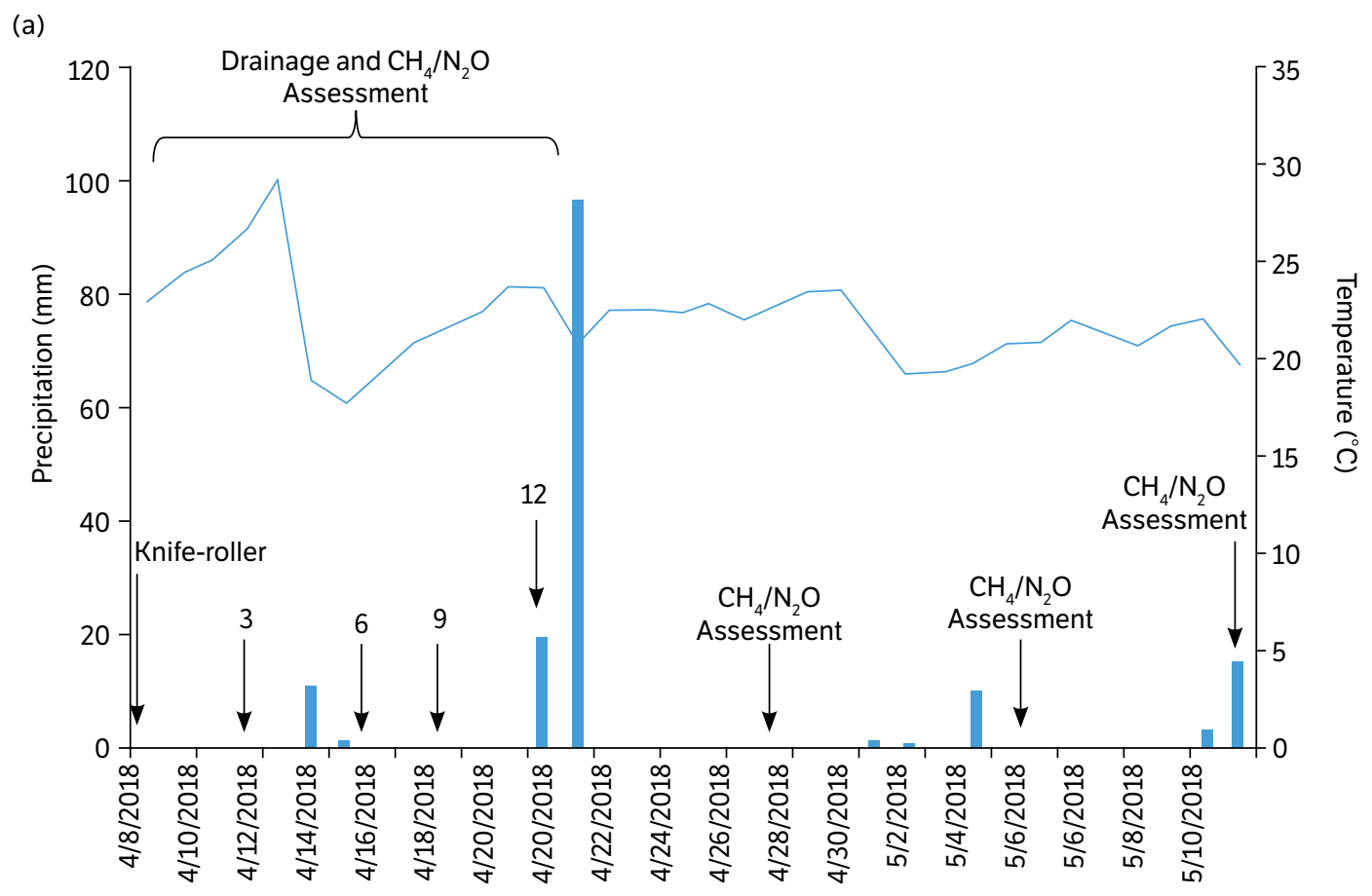

(b)

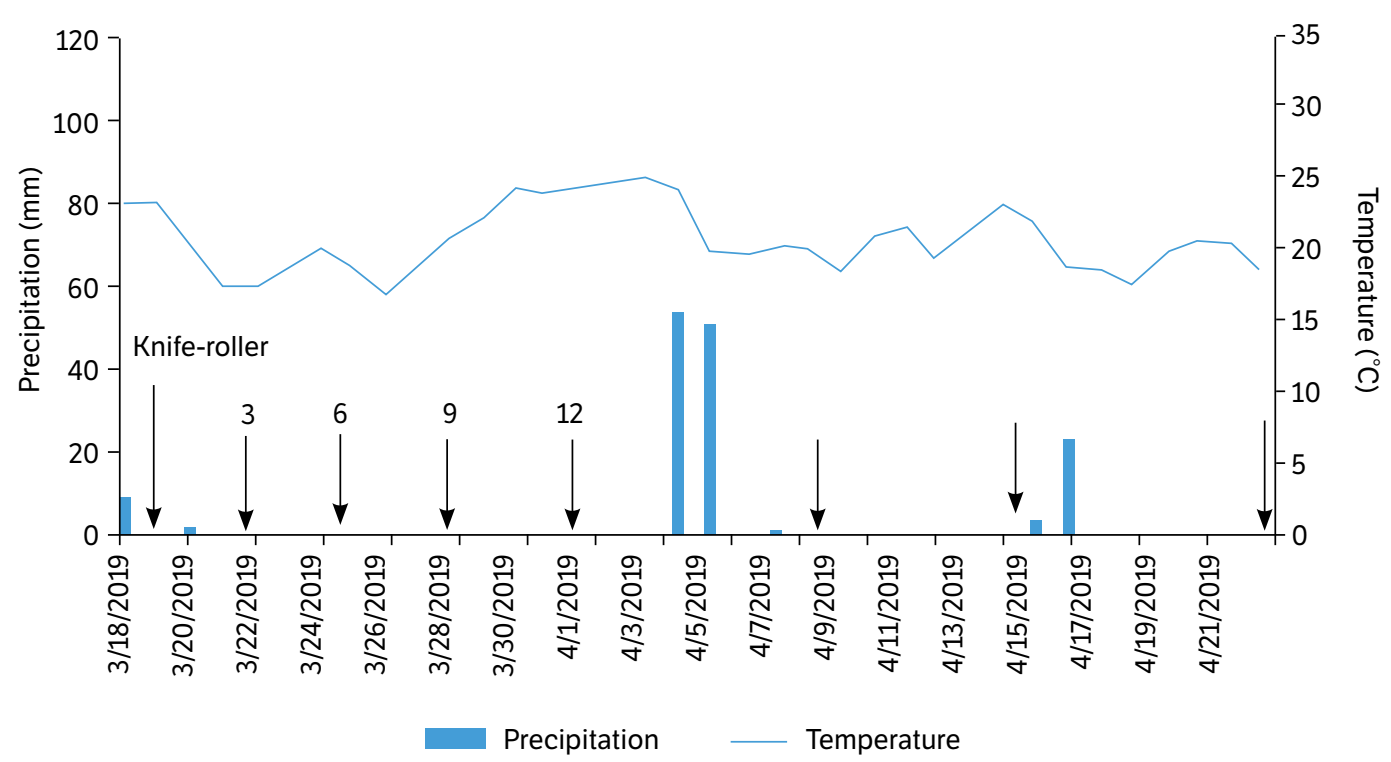

Figure 3. Mean daily air temperature $\left({ }^{\circ} \mathrm{C}\right)$ and daily rainfall $(\mathrm{mm})$ during the period of treatments application as well as greenhouse gas emission assessment during the 2018 (a) and 2019 (b) off-seasons.

Fe and Mn (Ponnamperuma 1972). Phosphorus has its dynamics modified due to adsorption on the surface of these oxides, and can be released in the soil solution (Teixeira et al. 2018).

However, this released concentration was not sufficient to observe high levels in the standing water. In addition, approximately 23 to $60 \%$ of the $P$ released from plant residues occurs between the $5^{\text {th }}$ and the $23^{\text {rd }}$ week after their incorporation (Singh et al. 2010). Thus, the soluble P concentrations in the current study were likely very low because the drainage period was less than two weeks.

With respect to the assessments of nitrate (Fig. $4 \mathrm{a}$ and b) and ammonium (Fig. 4c and d) in the drainage water, there were no differences between the treatments, over the two years. Such results can be explained by the timing of the last 
(a)

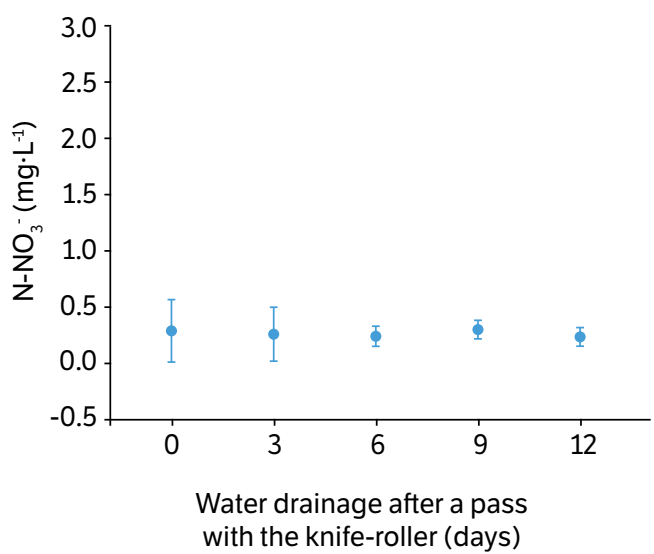

(c)

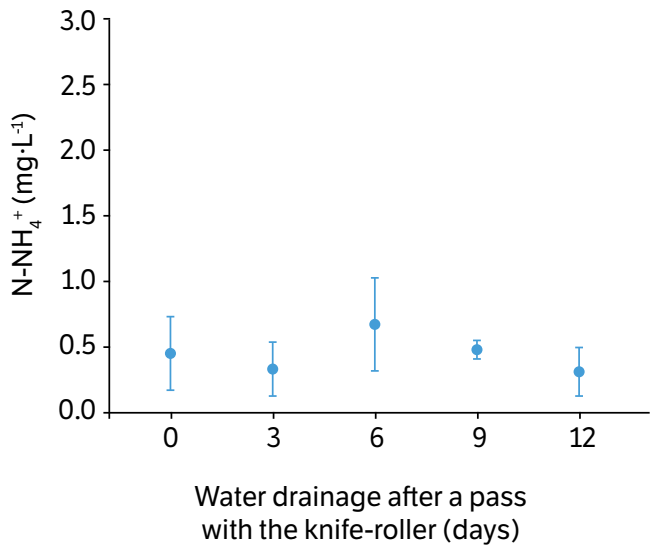

(b)

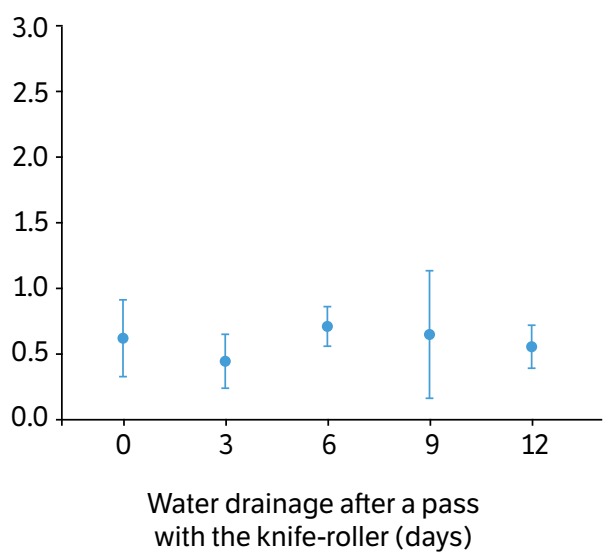

(d)

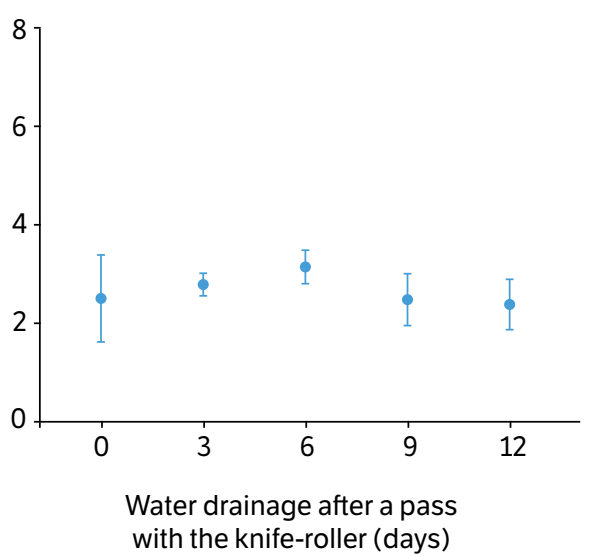

Figure 4. Nitrate $-\mathrm{N}-\mathrm{NO}_{3}^{-}\left(\mathrm{mg} \cdot \mathrm{L}^{-1}\right)$ and ammonium $-\mathrm{N}-\mathrm{NH}_{4}{ }^{+}\left(\mathrm{mg} \cdot \mathrm{L}^{-1}\right)$ in drainage water as a function of irrigated rice postharvest field management during the 2018 ( $a$ and c) and 2019 ( $b$ and d) off-seasons.

nitrogen application, which was carried out at the $\mathrm{R}_{0}$ phenological stage of irrigated rice, resulting in a time interval between this application and the collections longer than 60 days. After this period, nitrogen was no longer available, likely due to plant uptake and losses resulting from denitrification and volatilization.

With soil flooding, nitrification is reduced and there is an increase in denitrification potential. The low $\mathrm{NO}_{3}^{-}$content is related to changes in microbial activity, and the lack of oxygen ceases the nitrification process by mandatory aerobic microorganisms. Thus, under flooding, $\mathrm{NO}_{3}{ }_{3}^{-}$is the first oxidized compound used as a final electron acceptor by anaerobic and optional microorganisms in cellular respiration, being transformed into $\mathrm{N}_{2} \mathrm{O}$ and, later, $\mathrm{N}_{2}$. This process may have caused an increase in $\mathrm{N}_{2} \mathrm{O}$ in the soil solution (Fig. 5a). In addition to the losses, part of the applied $\mathrm{N}$ can be immobilized by the bacterial flora (Ponnamperuma 1972).

Besides the low concentration of nitrogen in the soil, rice straw is also characterized by low levels of $\mathrm{N}$, around $0.95 \%$ (Sun et al. 2019). Moreover, the sample collection period was less than 12 days after the knife-roller pass, a period which was not enough to release nitrogen from the plant residues. The anaerobic environment restricts the microbial population to a few species, which reduces decomposition and nitrogen release (Massoni et al. $2013 \mathrm{~b}$ ).

All these changes in the anaerobic environment directly depend on the residue management and interfere with the behavior of microorganisms and the dynamics of elements in the soil. As a consequence, they impact the atmospheric environment through greenhouse gas emissions. In this context, the presence of methanogenic bacteria, which are anaerobic and use $\mathrm{C}$ as the final electron acceptor, results in methane emissions $\left(\mathrm{CH}_{4}\right)$ while the nitrification and denitrification processes cause the nitrous oxide emissions $\left(\mathrm{N}_{2} \mathrm{O}\right)$.

The presence of standing water provides a favorable redox potential (Eh) for $\mathrm{CH}_{4}$ emissions. After flooding, Islam et al. (2018) observed that the beginning of $\mathrm{CH}_{4}$ production occurred when the soil redox potential (Eh) was $-127 \mathrm{mV}$ 

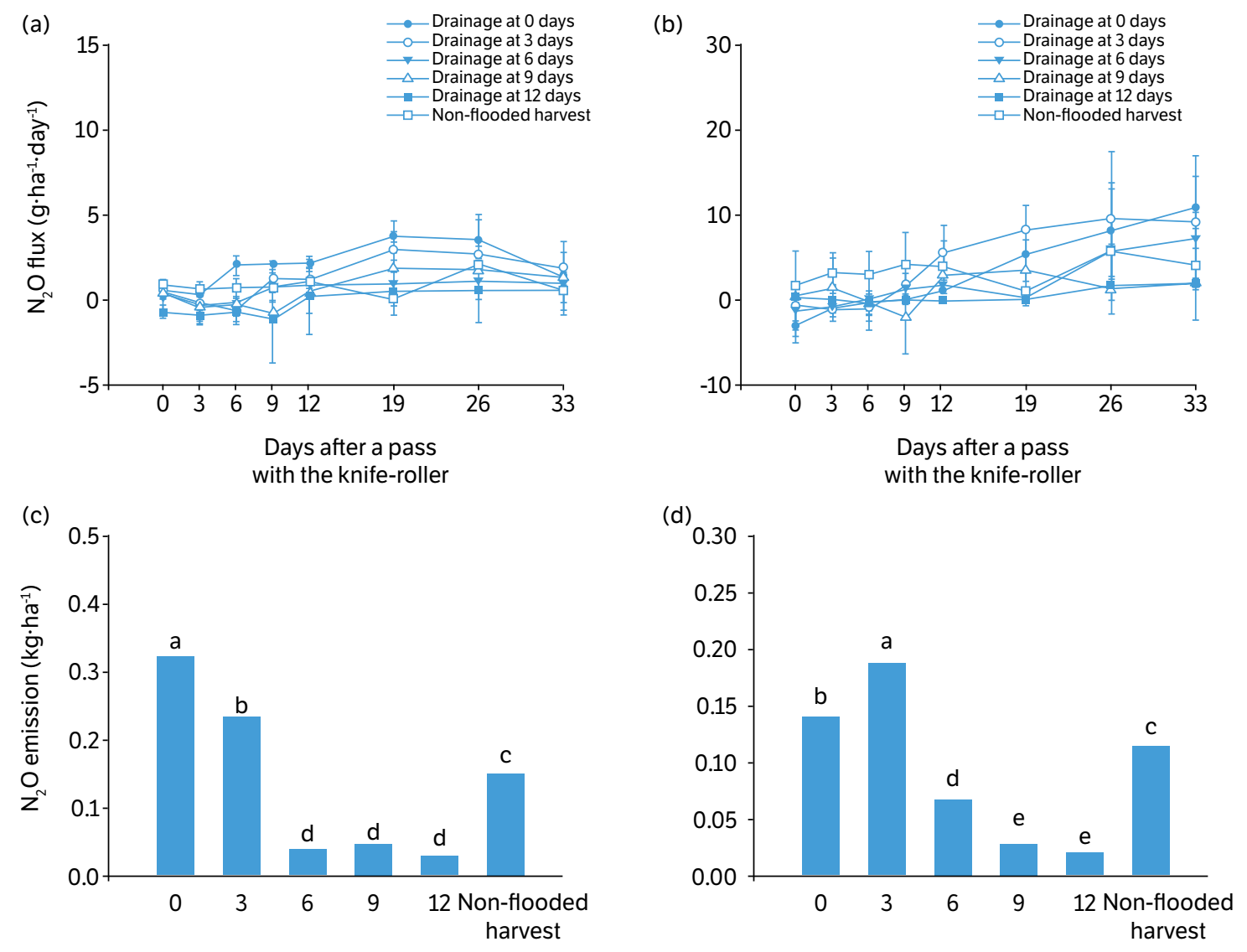

Water drainage after a pass with the knife-roller (days)
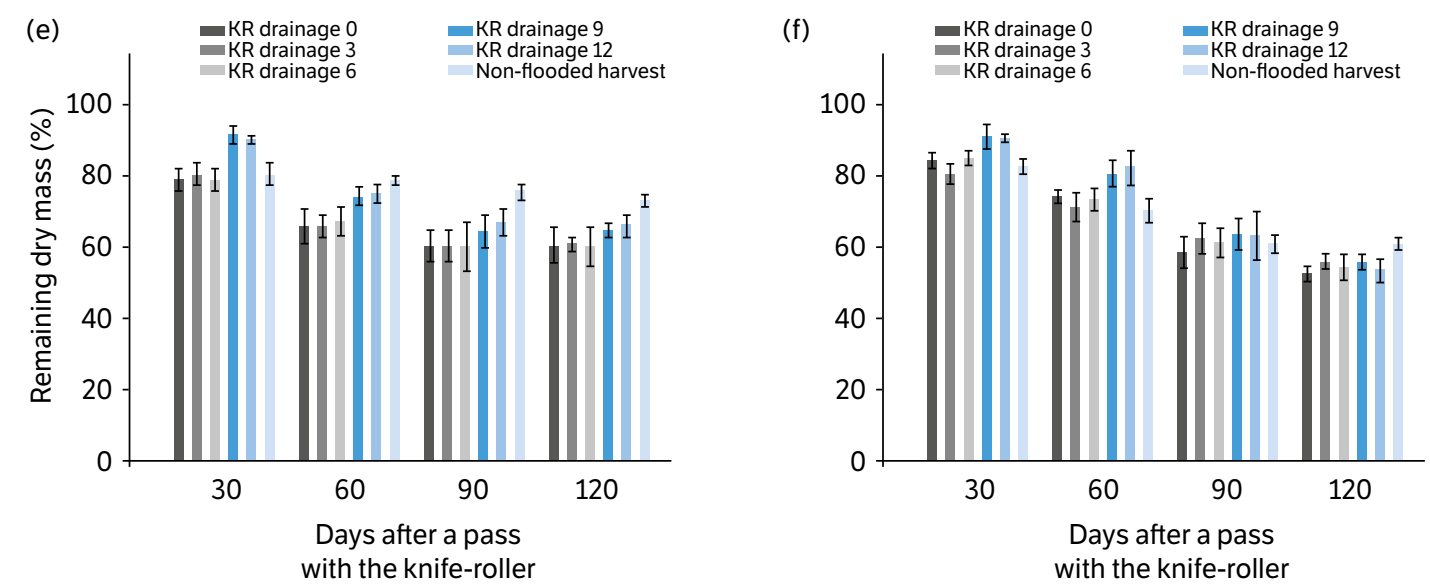

Figure 5. $\mathrm{N}_{2} \mathrm{O}$ daily flux $\left(\mathrm{g} \cdot \mathrm{ha}^{-1} \cdot \mathrm{day}^{-1}\right)$, total accumulation of $\mathrm{N}_{2} \mathrm{O}\left(\mathrm{kg} \cdot \mathrm{ha}^{-1}\right)$ and remaining dry mass $(\%)$ as a function of postharvest field management applied to the remaining rice straw, during the 2018 ( $a, c$ and e) and 2019 (b, $d$ and f) off-seasons. KR: knife-roller.

and, at 20 days after flooding, it obtained maximum reduction up to $-255 \mathrm{mV}$, with significant $\mathrm{CH}_{4}$ emissions. As such, during the two off-seasons higher emissions were observed under flooded than in the nonflooded harvest treatment. In the presence of standing water, the highest fluxes of $\mathrm{CH}_{4}$ observed were 15 and $4 \mathrm{~kg} \cdot \mathrm{ha}^{-1} \cdot \mathrm{day}^{-1}$ for 2018 and 2019 , respectively, while in the nonflooded treatment, the values were close to zero. These results corroborate data from Balaine et al. (2019), who observed daily $\mathrm{CH}_{4}$ fluxes of 8 and $6 \mathrm{~kg} \cdot \mathrm{ha}^{-1} \cdot \mathrm{day}^{-1}$ in flooded areas and values tending to zero under nonflooded conditions. 
As the treatments were applied and the water was drained, there was a reduction in the $\mathrm{CH}_{4}$ flux in the respective treatments, stabilizing after 12 DAKR in the first year (Fig. 6a). However, in the second year, the response differed, as there were flux oscillations due to precipitation (Fig. 6b). In both off-seasons, after the last drainage at $12 \mathrm{DAKR}$, there was rainfall of approximately $100 \mathrm{~mm}$ (Fig. 3a and b). However, in the first year, the interval between rain and assessment at 19 DAKR was 6 days, while in the second year, this interval was only 3 days. In addition, rainfall of $23 \mathrm{~mm}$ was recorded in the second year, resulting in a longer interval with presence of water in the treatment with drainage at $12 \mathrm{DAKR}$, and consequently an increase of $\mathrm{CH}_{4}$ fluxes.
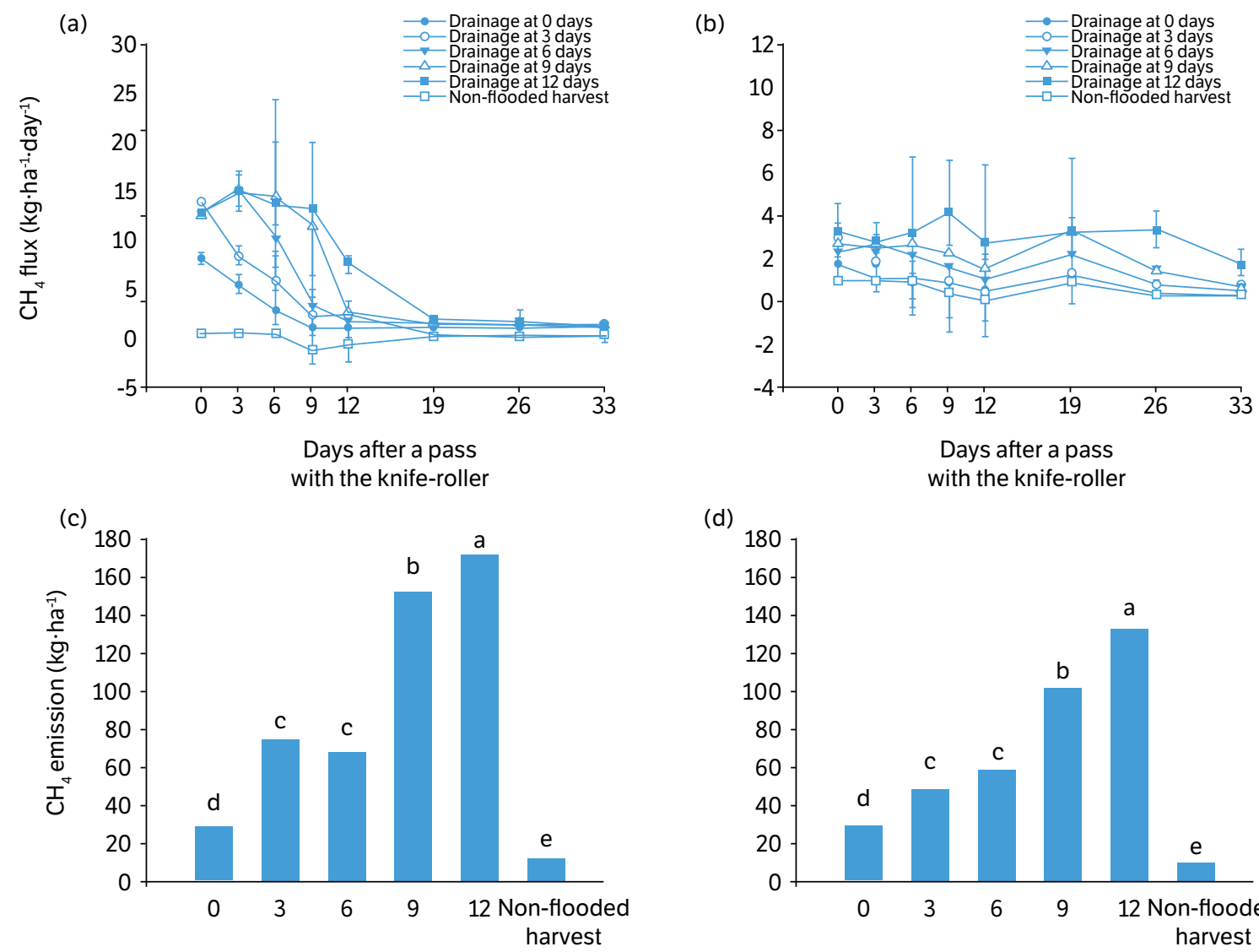

(d)

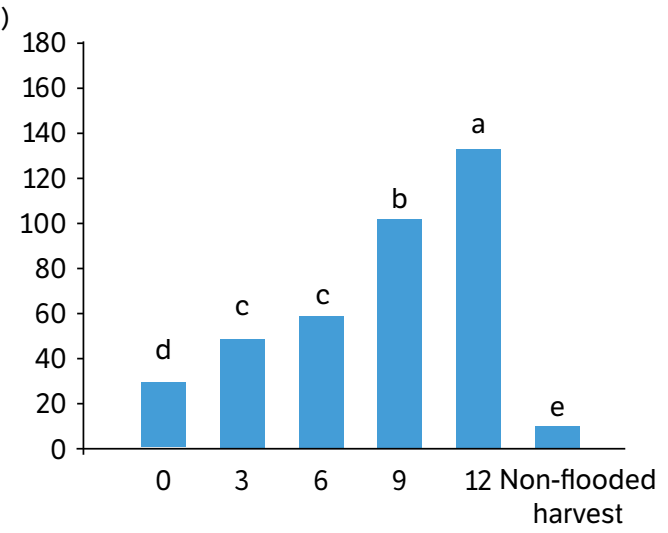

Water drainage after a pass

Water drainage after a pass with the knife-roller (days)

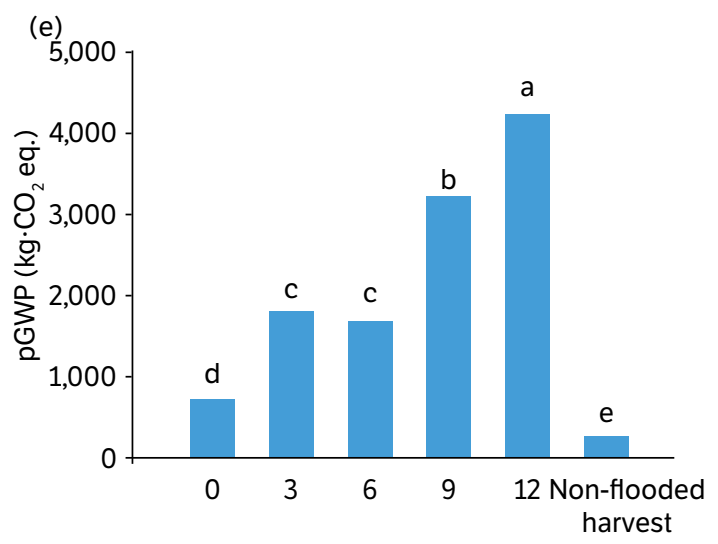

Water drainage after a pass with the knife-roller (days)

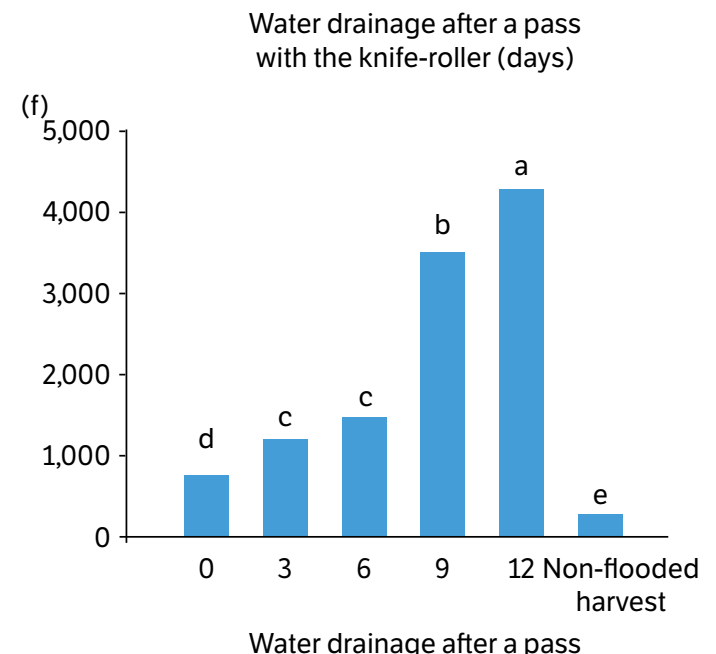

Water drainage after a pass with the knife-roller (days)

Figure 6. $\mathrm{CH}_{4}$ daily flux $\left(\mathrm{kg} \cdot \mathrm{ha}^{-1} \cdot \mathrm{day}^{-1}\right)$, total accumulation of $\mathrm{CH}_{4}\left(\mathrm{~kg} \cdot \mathrm{ha}{ }^{-1}\right)$ and partial global warming potential $-\mathrm{pGWP}(\mathrm{kg} \cdot \mathrm{CO} 2$ eq. $)$ as a function of postharvest field management applied to the remaining rice straw, during the 2018 (a, c and e) and 2019 (b, $d$ and f) off-seasons. 
The maximum daily $\mathrm{CH}_{4}$ emissions in this study were observed in the treatment, in which the straw was incorporated and the water depth remained for a longer period (12 days). For the first year, this peak was observed at $3 \mathrm{DAKR}$, with $15.79 \mathrm{~kg} \cdot \mathrm{ha}^{-1} \cdot \mathrm{day}^{-1}$, while for the second year, the highest rise was at zero days after the knife-roller pass, with $4.15 \mathrm{~kg} \cdot \mathrm{ha}^{-1} \cdot \mathrm{day}^{-1}$. The peaks observed in both years coincide with the highest temperature and where the straw was incorporated with a knife-roller. During the off-season, the most determinant factors for $\mathrm{CH}_{4}$ emissions are temperature, water depth and straw management (Martínez-Eixarch et al. 2018). According to Das and Adhya (2012), moisture and high temperature provide a favorable environment for the methanogenesis that is maximized by the better adaptation of the population of methanogenic bacteria to the environment.

The cumulative $\mathrm{CH}_{4}$ emissions were greater when drainage was performed at 9 and 12 DAKR in both years, and the initial fluxes were responsible for most of the emissions. In 2018, total emissions were 150 and $170 \mathrm{~kg} \cdot \mathrm{ha}^{-1}$ and, in 2019, 100 and $130 \mathrm{~kg} \cdot \mathrm{ha}^{-1}$ for the 9 and 12 DAKR, respectively. The total emission in these two treatments, in both years, was $75 \%$ higher in flooded than in the nonflooded treatment (Fig. 6c and d). Under straw management, the water depth contributes the most to the total methane emissions (Sander et al. 2018). The greater incorporation of straw into organic matter stimulates hydrolytic microbial activity under anaerobic conditions, resulting in accumulation of products from fermentation, increasing methanogenesis in the anoxic layer (Martínez-Eixarch et al. 2018) and consequently increasing $\mathrm{CH}_{4}$ emissions.

Regarding the dynamics of $\mathrm{N}_{2} \mathrm{O}$ emissions, the greatest peaks were observed 12 DAKR, coinciding with the precipitation during the collection period. The maximum $\mathrm{N}_{2} \mathrm{O}$ emissions were observed at zero DAKR drainage treatment for 2018 with $3.68 \mathrm{~g} \cdot \mathrm{ha}^{-1} \cdot$ day $^{-1}$ (Fig. 5a) and at 3 DAKR in 2019 with $10.7 \mathrm{~g} \cdot \mathrm{ha}^{-1} \cdot$ day $^{-1}$ (Fig. 5b). Sander et al. (2018) recorded greater fluxes in areas with successive moistening and drying cycles in relation to the presence of standing water, reaching $154.8 \mathrm{~g} \cdot \mathrm{ha}^{-1} \cdot \mathrm{day}^{-1}$.

Nitrous oxide is emitted by nitrification and denitrification processes, in which the contribution of the latter is the most important. Microbial denitrification is probably greater in well drained soils, which form $\mathrm{NO}_{3}^{-}$actively, becoming partially anaerobic after rainfall or after addition of an organic C source (Passianoto et al. 2003). In this sense, the increased straw in contact with the soil and the availability of labile $\mathrm{N}$, associated with precipitation, may have been responsible for the observed $\mathrm{N}_{2} \mathrm{O}$ peaks.

In relation to the total $\mathrm{N}_{2} \mathrm{O}$ emissions, the treatments with the shortest remaining standing water along with the nonflooded harvest were responsible for the largest accumulation. In the first year, the highest values were 0.32 and $0.23 \mathrm{~kg} \cdot \mathrm{ha}^{-1}$ for drainage at zero and 3 DAKR (Fig. 5c), respectively, being 85\% higher than the treatments with lower emission (6, 9 and 12 DAKR). For the second year, the maximum values were 0.14 and $0.19 \mathrm{~kg} \mathrm{ha}^{-1}$ for drainage at zero and 3 DAKR (Fig. $5 \mathrm{~d}$ ), respectively, $83 \%$ greater than those with lower emissions (6, 9 and 12 DAKR).

If the formed $\mathrm{N}_{2} \mathrm{O}$ diffuses into an aerated pore, it will be emitted into the atmosphere rather than converted to $\mathrm{N}_{2}$. However, when $\mathrm{N}_{2} \mathrm{O}$ is produced below the surface of a saturated soil, it is more likely to be reduced to $\mathrm{N}_{2}$ than to escape into the atmosphere. $\mathrm{N}_{2} \mathrm{O}$ emissions occur in most cases where the porous space occupied by water is less than $90 \%$. Under these conditions, more aerated soil pores can be found so that more $\mathrm{N}_{2} \mathrm{O}$ is emitted before being reduced (Sander et al. 2018).

The highest pGWP observed was $4000 \mathrm{~kg} \mathrm{CO}_{2}$ equiv.ha ${ }^{-1}$, in the drainage carried out at $12 \mathrm{DAKR}$, with the largest contribution of methane with variation from 82 to $99 \%$. Balaine et al. (2019) observed a higher pGWP in management with flooding water compared to nonflooded areas, reaching $11300 \mathrm{~kg} \mathrm{CO}_{2}$ equiv.ha- ${ }^{-1}$. Therefore, in an irrigated rice system, efforts to reduce pGWP should be primarily focused on methane instead of nitrous oxide, both during the crop cycle and during the off-season.

The postharvest field management, associated with edaphic characteristics such as soil temperature and humidity (Nakajima et al. 2016), interferes directly with the decomposition of rice straw, and the increase of residue in contact with the soil favors the release of labile $\mathrm{C}$ and $\mathrm{N}$ (Hoang et al. 2019), facilitating the decomposition by the microbial population. Botta et al. (2015) observed that the use of a knife-roller reduced the remaining straw by $54.5 \%$ during a period of 210 days in relation to the area without interventions.

In this sense, greater decomposition was observed where there was incorporation with the knife-roller, as the remaining dry mass at the end of the evaluation period, decreased by $15 \%$ for the first year (Fig. 5e) and $6 \%$ for the second year (Fig. 5f), in relation to the nonflooded harvest without incorporation. The release of $\mathrm{C}$ and $\mathrm{N}$ is described as a fast-initial phase, 
followed by a slow one, which are related to the biochemical composition of the material. The initial phase is characterized by the degradation of compounds present in the labile compartments, which are more easily mineralizable. In the later phase, decomposition occurs with compounds in recalcitrant compartments, which are more difficult to be mineralized (Giacomini et al. 2003).

For treatments with drainage at 9 and 12 DAKR, the rapid initial $\mathrm{C}$ and $\mathrm{N}$ release phase was not observed, as the accumulated precipitations were 345 and $201 \mathrm{~mm}$ (Fig. 7a and b) during the first and second years, respectively, which helped the soil to remain in an anaerobic environment, reducing microbial activity. Although the greater contact of the straw with the soil facilitates the release of $\mathrm{C}$ and $\mathrm{N}$, depending on climatic variables, the straw incorporation with the knife-roller can reduce degradation. Throughout the evaluations, it was observed that precipitation directly influenced the degradation process, because the treatment with straw on the surface hindered the rates of water loss during periods with a high volume of rain. However, it was observed that, when there was a reduction in precipitation volume, associated with temperature fluctuations, the straw benefited the decomposition process by conserving the available humidity and by avoiding a large thermal amplitude.

It is important to consider that, climate, soil and location may cause a variation in the parameters evaluated in this experiment. In addition, for better recommendations in relation to postharvest, studies with cover crops and direct sowing in lowland areas should still be carried out, in order to reduce soil mobilization during the off-season.

(a)

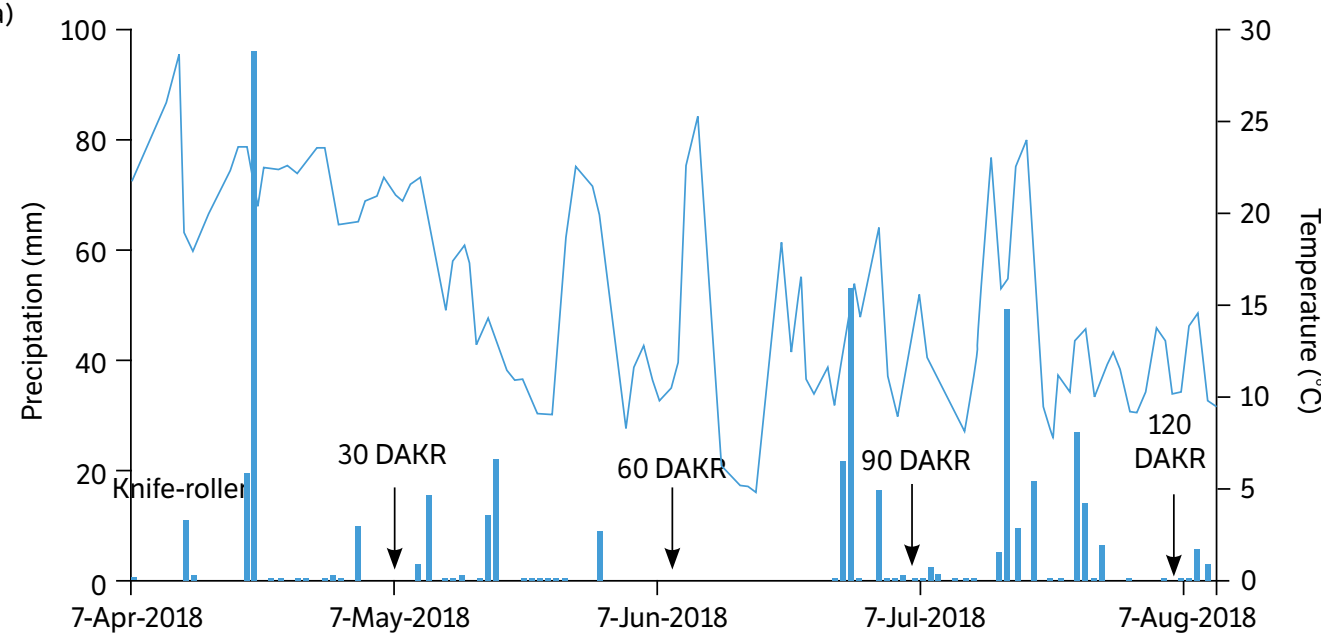

(b)

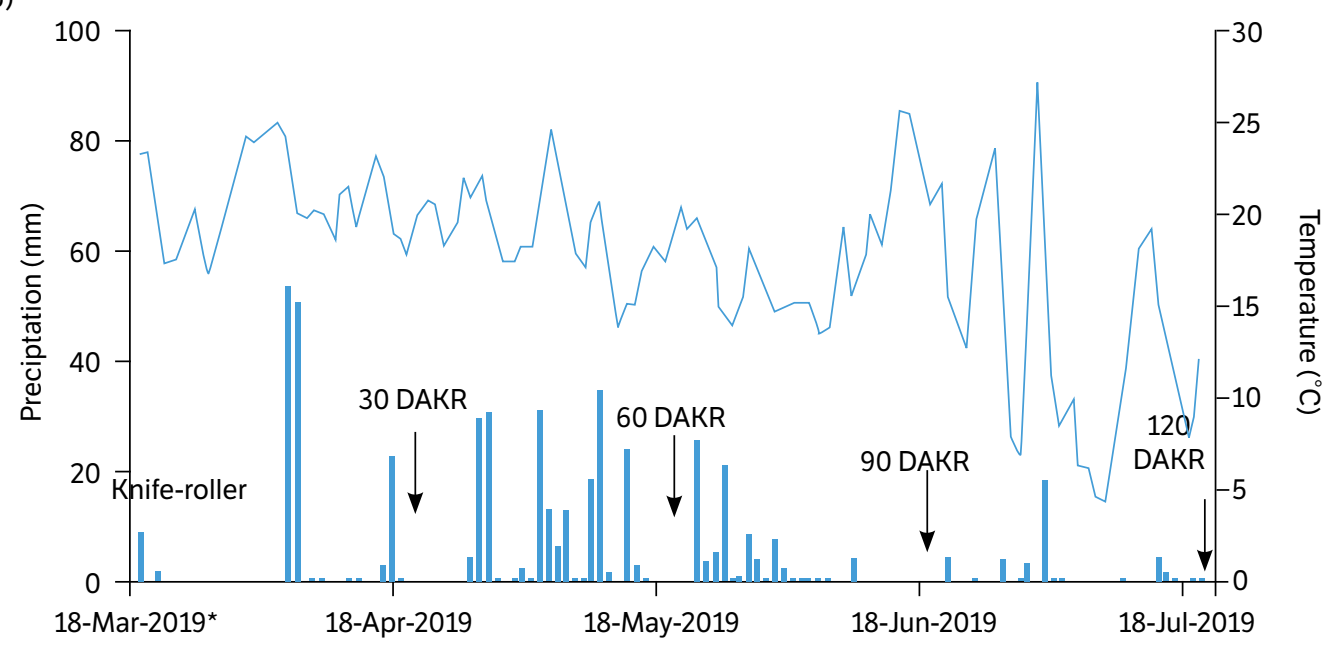

Figure 7. Mean daily air temperature $\left({ }^{\circ} \mathrm{C}\right)$ and daily rainfall $(\mathrm{mm})$ during the collection of the "mesh bags" during the $2018(\mathrm{a})$ and $2019(\mathrm{~b})$ off-seasons. DAKR:days after a pass with knife-roller. 


\section{CONCLUSION}

Nonflooded harvest reduces the partial global warming potential and decreases the soil particles loss as well as nutrients in the field. If nonflooded harvest is not possible, an incorporation of straw with the use of a knife-roller in standing water accelerates the process of plant residues decomposition.

The drainage of water three days after a pass with the knife-roller in a planosol reduces the loss of potassium and soil via drainage water. Maintaining standing water for more than nine days increases $\mathrm{CH}_{4}$ emissions and the partial global warming potential.

\section{FUNDERS}

Coordenação de Aperfeiçoamento de Pessoal de Nível Superior

[http://doi.org/10.13039/501100002322]

Conselho Nacional de Desenvolvimento Científico e Tecnológico

[http://doi.org/10.13039/501100003593]

Fundação de Amparo à Pesquisa do Estado do Rio Grande do Sul

[http://doi.org/10.13039/501100004263]

\section{AUTHOR'S CONTRIBUTION}

Conceptualization, Soares, C. F., Marchesan E., Minella, J. P. G. and Prochnow, M. H.; Methodology, Soares, C. F., Lúcio, A. D. and Oliveira, D. S.; Investigation, Soares, C. F., Fleck, A. G., Prochnow, M. H., Riste, U. S. and Oliveira, D. S.; Writing - Original Draft, Soares, C. F.; Writing - Review and Editing, Soares, C. F., Marchesan, E. and Oliveira, D. S.; Funding Acquisition, Soares, C. F. and Marchesan, E.; Resources, Marchesan, E.; Supervision, Marchesan E.

\section{REFERENCES}

Balaine, N., Carrijo, D. R., Adviento-Borbe, M. A. and Linquist, B. (2019). Greenhouse gases from irrigated rice systems under varying severity of alternate-wetting and drying irrigation. Soil Science Society of America Journal, 83, 1533-1541. https://doi.org/10.2136/ sssaj2019.04.0113

Botta, G. F., Tolón-Becerra, A., Lastra-Bravo, X., Hidalgo, R., Rivero, D. and Agnes, D. (2015). Alternatives for handling rice (Oryza sativa L.) straw to favor its decomposition in direct sowing systems and their incidence on soil compaction. Geoderma, 239-240, 213-222. https://doi.org/10.1016/j.geoderma.2014.10.021

CLIMATE-DATA.ORG. (2019). Climate data for cities worldwide. [Accessed Nov. 07, 2019]. Available at: https://en.climate-data.org

Das, S. and Adhya, T. K. (2012). Dynamics of methanogenesis and methanotrophy in tropical paddy soils as influenced by elevated $\mathrm{CO}_{2}$ and temperature interaction. Soil Biology and Biochemistry, 47, 36-45. https://doi.org/10.1016/j.soilbio.2011.11.020

Fia, R., Tadeu, H. C., Menezes, J. P. C., Fia, F. R. L. and Oliveira, L. F. C. (2015). Qualidade da água de um ecossistema lótico urbano. Revista Brasileira de Recursos Hídricos, 20, 267-275. https://doi.org/10.21168/rbrh.v20n1.p267-275 
Giacomini, S. J., Aita, C., Hübner, A. P., Lunkes, A., Guidini, E. and Amaral, E. B. (2003). Liberação de fósforo e potássio durante a decomposição de resíduos culturais em plantio direto. Pesquisa Agropecuária Brasileira, 38, 1097-1104. https://doi.org/10.1590/ S0100-204X2003000900011

Hoang, T. T. H., Do, D. T., Tran, T. T. G., Ho, T. D. and Rehman, H. (2019). Incorporation of rice straw mitigates $\mathrm{CH}_{4}$ and $\mathrm{N}_{2} \mathrm{O}$ emissions in water saving paddy fields of Central Vietnam. Archives of Agronomy and Soil Science, 65, 113-124, https://doi.org/10.1080/03650340 .2018 .1487553

Islam, S. F., van Groenigen, J. W., Jensen, L. S., Sander, B. O. and Neergaard, A. (2018). The effective mitigation of greenhouse gas emissions from rice paddies without compromising yield by early-season drainage. Science of The Total Environment, 612, 1329-1339. https://doi.org/10.1016/j.scitotenv.2017.09.022

Jumadi, O., Hartono, H., Masniawati, A., Iriany, R. N., Makkulawu, A. T. and Inubushi, K. (2019). Emissions of nitrous oxide and methane from rice field after granulated urea application with nitrification inhibitors and zeolite under different water managements. Paddy and Water Environment, 17, 715-724. https://doi.org/10.1007/s10333-019-00724-3

Kondoh, T., Nagasaka, Y., Kato, A., Shindo, H., Kato, M., Saito, M., Fujiwara, K., Yamamoto, S. and Yaji, Y. (2019). Reduction of nitrogen, phosphorus and suspended solids effluent loads from paddy fields by transplanting into retained ponding water using a GNSS-controlled rice transplanter. Paddy and Water Environment, 17, 221-230. https://doi.org/10.1007/s10333-019-00714-5

Li, J., Lu, J., Li, X., Ren, T., Cong, R. and Zhou, L. (2014). Dynamics of potassium release and adsorption on rice straw residue. PLoS ONE, 9, e90440. https://doi.org/10.1371/journal.pone.0090440

Martínez-Eixarch, M., Alcaraz, C., Viñas, M., Noguerol, J., Aranda, X., Prenafeta-Boldú, F. X., Veja, J. A. S., Català, M. M. and Ibáñez, C. (2018). Neglecting the fallow season can significantly underestimate annual methane emissions in Mediterranean rice fields. PLoS ONE, 13, e0198081. https://doi.org/10.1371/journal.pone.0198081

Massoni, P. F. S., Marchesan, E., Grohs, M., Roso, R., Coelho, L. L., Machado, S. L. O., Teló, G. M. and Lúcio, A. D. (2013 a) Influência de manejos pós-colheita do arroz irrigado sobre o banco de sementes de arroz-vermelho. Planta Daninha, 31, 89-98. https://doi.org/10.1590/ S0100-83582013000100010

Massoni, P. F. S., Marchesan, E., Grohs, M., Silva, L. S. and Roso, R. (2013 b). Nutrientes do solo influenciados por diferentes manejos da palha após a colheita do arroz irrigado. Revista Ciência Agronômica, 44, 205-214. https://doi.org/10.1590/S1806-66902013000200001

Mosier, A. R. (1989). Chamber and isotopic techniques. In M. O. Andrea and D. S. Schimel (Eds.), Exchange of trace gases between terrestrial ecosystems and the atmosphere: report of the Dahlem Workshop on Exchange of Trace Gases between Terrestrial Ecosystems and the Atmosphere, Berlin 1989, February 19-24 (p. 175-187). Chichester: Wiley.

Nakajima, M., Cheng, W., Tang, S., Hori, Y., Yaginuma, E., Hattori, S., Hanayama, S., Tawaraya, K. and Xu, X. (2016). Modeling aerobic decomposition of rice straw during the off-rice season in an Andisol paddy soil in a cold temperate region of Japan: Effects of soil temperature and moisture. Soil Science and Plant Nutrition, 62, 90-98. https://doi.org/10.1080/00380768.2015.1121116

Passianoto, C. C., Ahrens, T., Feigl, B. J., Steudler, P. A., Carmo, J. B. and Melillo, J. M. (2003). Emissions of CO ${ }_{2} \mathrm{~N}_{2} \mathrm{O}$ and NO in conventional and no-till management practices in Rondônia, Brazil. Biology and Fertility of Soils, 38, 200-208. https://doi.org/10.1007/s00374-003-0653-y

Ponnamperuma, F. N. (1972). The chemistry of submerged soils. Advances in Agronomy, 24, 29-96. https://doi.org/10.1016/ S0065-2113(08)60633-1

Sander, B. O., Samson, M., Sanchez, P. B., Valencia, K. P., Demafelix, E. A. M. and Buresh, R. J. (2018). Contribution of fallow periods between rice crops to seasonal GHG emissions: effect of water and tillage management. Soil Science and Plant Nutrition, 64, $200-209$. https://doi.org/10.1080/00380768.2018.1440937

Santos, H. G., Jacomine, P. K. T., Anjos, L. H. C., Oliveira, V. A., Lumbreras, J. F., Coelho, M. R., Almeida, J. A., Araujo Filho, J. C., Oliveira, J. B. and Cunha, T. J. F. (2018). Sistema Brasileiro de Classificação de Solos. Brasília: Embrapa. 
Shah, K. A. and Joshi, G. S. (2017). Evaluation of water quality index for River Sabarmati, Gujarat, India. Applied Water Science, 7, 13491358. https://doi.org/10.1007/s13201-015-0318-7

Shreve, E. A. and Downs, A. C. (2005). Quality-assurance plan for the analysis of fluvial sediment by the U.S. Geological Survey Kentucky Water Science Center Sediment Laboratory. Open-File Report 2005-1230. Reston: U.S. Geological Survey. https://doi. org/10.3133/ofr20051230

Silva, J. J. C., Theisen, G., Andres, A., Silva, J. L. S. and Idehara, S. J. (2012). Avaliação do uso de rolo-faca no preparo do solo pós-colheita do arroz irrigado em áreas da Planície Costeira do RS [Documento 349]. Pelotas: Embrapa Clima Temperado. [Accessed Apr. 30, 2020]. Available at: https://ainfo.cnptia.embrapa.br/digital/bitstream/item/78763/1/Documento-349.pdf

Singh, Y., Gupta, R. K., Singh, J., Singh, G., Singh, G. and Ladha, J. K. (2010). Placement effects on rice residue decomposition and nutrient dynamics on two soil types during wheat cropping in rice-wheat system in northwestern India. Nutrient Cycling in Agroecosystems, 88, 471-480. https://doi.org/10.1007/s10705-010-9370-8

SOSBAI (2018). Arroz irrigado: recomendações técnicas da pesquisa para o sul do Brasil. Pelotas: Sociedade Sul-Brasileira de Arroz Irrigado.

Sun, K., Cao, W., Hu, L. Y., Fu, W. Q., Gong, J. H., Kang, N. and Dai, C. C. (2019). Symbiotic fungal endophyte Phomopsis liquidambaririce system promotes nitrogen transformation by influencing below-ground straw decomposition in paddy soil. Journal of Applied Microbiology, 126, 191-203. https://doi.org/10.1111/jam.14111

Tedesco, M. J., Volkweiss, S. J. and Bohnen, H. (1995). Análises de solo, plantas e outros materiais. Porto Alegre: Departamento de Solos da UFRGS.

Teixeira, J. B. S., Sousa, R. O. and Vale, M. L. C. (2018). Phosphorus adsorption after drainage in two soil classes. Revista Ceres, 65, 196203. https://doi.org/10.1590/0034-737×201865020012

Wu, X., Wang, W., Xie, X., Hou, H. and Yin, C. (2018). Response of $\mathrm{N}_{2} \mathrm{O}$ emission to straw retention under two contrasting paddy water conditions: a field experiment over rice-rice-fallow rotation. Paddy and Water Environment, 16, 199-205. https://doi.org/10.1007/ s10333-017-0621-z

Xiao, M., Yu, S., She, D., Hu, X. and Chu, L. (2015). Nitrogen and phosphorus loss and optimal drainage time of paddy field under controlled drainage condition. Arabian Journal of Geosciences, 8, 4411-4420. https://doi.org/10.1007/s12517-014-1540-6 